\section{A New Subtractive Colour Film}

The Eastman Kodak Company has introduced a new $16 \mathrm{~mm}$. cinematograph colour film. This is known as the Kodachrome film. It differs from many other colour films now available in that the colour effects are produced 'subtractively'. The superimposition of 'minus' colours is used to yield the final colour. For example, a blue is produced by placing a minus green (magenta) on a blue-green (minus red), green by minus blue (yellow) on a minus red and so on. This is, of course, the ordinary principle of three-colour printing, but to apply it to this process has involved the use of a film coated in three layers. Each of these layers records one of the primary colours only. The top layer is sensitive to blue and transmits only green and red; the second layer records green and transmits red, while the last layer of all records only red. The film is exposed in the ordinary way and has a sensitivity which is said to be about half that of the normal film used for black-and-white cinematography. Processing is divided into a number of separate processes : (1) Development to negative. (2) Bleaching and clearing to get rid of the developed silver. (3) Exposure and redevelopment to positive. This redevelopment is carried out with a 'dyecoupling developer' which attaches a blue-green dye to the silver produced by development. All three layers are treated indiscriminately up to this point. Then follow further stages. (4) Bleaching the two upper layers ; silver chloride is formed in place of the silver in these layers and the blue-green dye in them is destroyed. (5) Exposure and redevelopment of the two upper layers with a magenta coupling developer. (6) Bleaching the top layer and destroying the magenta dye. (7) Exposure and development of the top layer with a yellow coupling developer. The pictures so formed are continuous in tone.

\section{Spelæological Research in Great Britain}

A PRoposal to form a central organisation for the co-ordination of research in the caves and pot-holes of Britain is to be discussed at an inaugural meeting to be held on July 27 at the Museum, The Wardwick, Derby. Among those taking an active part in forwarding the movement are Prof. L. S. Palmer (Hull), Mr. A. Leslie Armstrong (Sheffield), Dr. J. W. Jackson (Manchester), Dr. A. Raistrick (Durham), Mr. H. Brodrick (Birkdale), and Mr. C. R. Hewer (Bristol University Spelæological Society). Prof. L. S. Palmer will act as chairman of the meeting, when aims and methods which will best promote systematic exploration of British caves on comprehensive lines, embracing all relevant forms of evidence, will be discussed. The proposal most favoured at present is the constitution of a British Spelæological Association, which would lead the way to a standardisation of technique and afford opportunity for coordination of results. Cave exploration in Britain has by no means been neglected, as the exploration of Kent's Cavern, Torquay, and Boyd Dawkins' classic work on "Cave Hunting" bear witness. The pot-holes clubs and antiquarian societies of the north of England have devoted considerable attention to it, and the activities of the Bristol University Spelæological Society, Mr. Leslie Armstrong and Prof. Palmer have been remarkably fruitful in additions to archæological knowledge, especially of the palæolithic period. It is felt, however, that co-operation between individuals and organisations interested in the problems of cave-dwelling man and his environment will facilitate further research and preserve the enthusiasm of explorers from unprofitable, and even harmful, activity by ensuring greater uniformity in the observance of scientific methods of explorationa view in which archæologists, at least, will heartily concur.

\section{Lulham Memorial Fund}

Mrss Rosalie Lulfam, who died on December 28, 1934, was well known as a field naturalist and for her work as a teacher of natural history. During the last year of her life she was actively concerned in planning a course of training in natural history for students, teachers and others with previous scientific training, who, to quote her own words, "wish to make that practical study of living things both outdoors and indoors, which would enable them to teach live Natural History, making it the absorbing and enlightening subject it may be". Such a course of training is being established at the Froebel Institute, where she worked for thirty-eight years, and where the tradition of her teaching is living and growing in the Natural History Department built up by her efforts. The College of the Institute at Roehampton Lane, London, S.W.15, with its spacious grounds and its proximity to Richmond Park, offers excellent scope for practical study in natural history, and it has been suggested that a Lulham Memorial Fund be opened with the object of equipping the Science Department for advanced study in natural history. We trust that this appeal will meet with ready response not only from those who, directly or indirectly, shared the inspiration of her teaching, but also from those who believe that there is a real educational need for encouraging the teaching of biology through the study of living Nature. Donations should be sent to Dr. A. B. Rendle, c/o British Museum (Natural History), Cromwell Road, London, S.W.

\section{Television in the Cinema}

Captain A. G. West, of the Baird Television Co., Ltd., gave a very instructive address to the Cinematograph Exhibitors' Association at Cardiff on June 26. A summary of this address appears in the Electrician for July 5. He pointed out that the only possible waves that can be used to produce high-definition pictures are ultra-short waves the lengths of which are not greater than 10 metres. If a 6 -metre length is used, then the necessary breadth of the band need lie only between 5.9 metres and $6 \cdot 1$ metres. If it be operated on 300 metres, it would interfere with many of the broadcasting stations in Europe. Ultrashort waves have almost the same properties as waves of light and thus cast shadows. The transmitting aerials on the top of the Crystal Palace tower are 
$700 \mathrm{ft}$. above sea-level and in most directions give an effective range of transmission of about 40 miles. In his opinion, the best all-round wave-length for television is 7 metres, which does to a certain extent curve round hills to more distant points. A large number of tests have been carried out in all parts of London in receiving pictures from the Crystal Palace transmitter. Excellent pictures have also been received at some fifty sites ranging from Southend to Maidenhead and from Hatfield to Sevenoaks. In two years time, it may be possible to buy a complete set for the home for about 35 guineas. For cinema work, he thought that the best method is to use an intermediate film. A film is taken of the scene to be transmitted. It is then developed, fixed, washed and dried before being televised, the whole operation being less than two minutes. The first cinemas to receive their programmes by television would get them by radio transmission links. Later on, the big central radio transmitter might conveniently be replaced by a central distributing exchange point, which would receive the televising waves by cable from the outside point possibly twenty miles away.

\section{Italian Breakwater Construction}

On July 9, at the invitation of the Council, a special lecture, illustrated by lantern views, was delivered at the Institution of Civil Engineers, by Prof. E. Coen Cagli, of the School of Engineering of Rome. Prof. Cagli reviewed very exhaustively the progress made during recent years at Italian harbours and gave particulars of the present accommodation and equipment at the leading ports. He related how, on his recommendation, following an official visit a number of years ago to Great Britain for the purpose of studying British methods and practice, the vertical wall type of breakwater came to be adopted in Italy, and he stated that, with the exception of an unfortunate experience at Catania, attributable to absence of vertical bond in the structure, the results had been uniformly successful. He described the catastrophic storm of March 26-27, 1933, which caused the displacement of 700 lineal metres of newly constructed breakwater at that port and compared it with the similar catastrophe which befell the second arm of the Mustapha Jetty at Algiers on Feb. 2-3 of the following year (vide NATURE, 135, 143, Jan. 26, 1935), giving it as his opinion that these two incidents, on an analysis of the attendant conditions, only served to confirm his judgment in favour of the vertical wall breakwater. This type, moreover, had received further support from a series of experimental tests with small scale models, which he had been conducting with the co-operation of Prof. Stuckey at the hydrological laboratory of the University of Lausanne. Prof. Coen Cagli closed his lecture with a statement of the series of conclusions at which he had arrived on the basis of his experimental investigations.

\section{Foundation for Theoretical Biology at Leyden}

To promote the study and work in the field of theoretical biology, a foundation for theoretical animal and human biology has been established at the University of Leyden. In memory of Van der Hoeven (1801-68), professor of zoology in the University and author of the "Philosophia Zoologica", it is called "Prof. Dr. Jan van der Hoeven Stichting voor theoretische biologie van dier en mensch". The chief objects of the foundation are: (1) to arrange for lectures at the University of Leyden; (2) to bring Leyden biologists who are interested in theoretical biology into contact with their colleagues in Holland and abroad; and to promote the cooperation of theoretical biologists all over the world, for example, by arranging international symposia on theoretical biology; (3) to publish articles on theoretical biology; (4) to found a library on this subject. The directors of the Foundation are: Dr. C. J. van der Klaauw, professor of general zoology at the University of Leyden, Dr. J. A. J. Barge, professor of medical anatomy at the University of Leyden, and Dr. Adolf Meyer, professor of theoretical biology at the University of Hamburg.

\section{U.S. Stratosphere Balloon Explorer II}

MIsfortune has attended this latest attempt at stratosphere research. An account of the careful preparations that had been made jointly by the National Geographic Society and the U.S. Army Air Corps appeared in NATURE of June 22 (p. 1026) and the largest balloon ever designed was scheduled to be ready by June 1. A message in The Times of July 12 reports, however, that whilst the gondola was being attached on the previous day, the balloon burst for some unaccountable reason; the $375,000 \mathrm{cu}$. $\mathrm{ft}$. of helium were lost, and the five men working below had to jump for their lives to escape from the falling mass of the collapsing envelope. From the brief report it would appear as though the whole of the 8 tons upward force was too much for the initial cylindrical form assumed by the envelope, with the result that the top blew out.

\section{The New York Aquarium}

THE thirty-eighth annual report of the New York Zoological Society includes the report of the director of the Aquarium, Mr. Charles M. Breder, Jr., assistant director (June 1934). Some of the larger exhibits, including aquatic mammals, have been discontinued, but there is a larger number of fishes, so that the total number of species and specimens is greater than before. The work of the laboratory for the most part was concerned with studying various details of aquarium operation for the improvement of life conditions of fishes in captivity, including water chemistry, control of parasites and bacteria, food and breeding. A new antiseptic, 'mesthiolate', was found to be of distinct value in the control of secondary bacterial infection and in overcoming attacks of the protozoan Costia. Young brine shrimps, Artemia salina, reared from dried eggs supplied by the San Francisco Aquarium Society, have proved an excellent food for the sea-horses and other small fishes. With some little trouble, the shrimps may be raised to a considerable size suitable for larger species. 